\title{
A HONI ÁLLAMI EGYETEM MINT TUDÁSALKOTÓ SZERVEZET EGYES SZERVEZETI TULAJDONSÁGAI
}

A szerzók a honi állami egyetem, mint tudásalkotó szervezet egyes szervezeti tulajdonságait mutatják be a Budapesti Múszaki és Gazdaságtudományi Egyetemen megfigyelt szervezetimagatartás-formákat alapul véve. A tanulmányban megvizsgálják, hogy melyek azok a - gyenge erôsségú piaci környezetben múködő - tudásvállalati szervezeti viselkedési jegyek, melyek leginkább befolyásolják valamely állami egyetem szervezeti tulajdonságait. A vizsgálathoz kiindulásképpen feltételezték, hogy az egyetemek kreatív szervezetek.

Kulcsszavak: honi állami egyetem, kreatív szervezet, tekintélyelv, munkakörvizsgálat

A kreatív szervezetekkel foglalkozó irodalom nem foglalkozik azzal, hogy milyen hátrányai lehetnek, ha a szervezeti kultúrára nem jellemzô az erốteljes piaci koordináció.

Az 1. táblázatban - múegyetemi megfigyeléseinkre támaszkodva - bemutatjuk a kreatív szervezettel kap- csolatos problémákat abban az esetben, ha a piaci és a külső bürokratikus koordináció (Kornai, 1983) szerepe gyönge, és a szervezet leginkább - legalábbis hagyományaiban és vallott értékrendszerében - az etikai koordináció ethosza szerinti (Gyökér - Finna - Krajcsák - Szabó, 2008).

Kreatív szervezet gyenge piaci orientációval

\begin{tabular}{|c|c|c|}
\hline A kreativitás tényezói & Problémák & A kreatív szervezet tulajdonságai \\
\hline Fluencia & $\begin{array}{l}\text { - az ötletek többsége a munkavállalók önérdekéhez } \\
\text { kapcsolódóan öncélú, vagy át nem gondolt } \\
\text { - a nyilvánvalóan ostoba ötletekkel is foglakoznia kell a } \\
\text { vezető́knek, mert (egyébként jellemzóen más területen) } \\
\text { kreatív emberek adták, akik megsértődnek, ha közlik velük, } \\
\text { hogy saját szakterületükön kívül eső dolgokban már nem } \\
\text { automatikusan kompetensek }\end{array}$ & $\begin{aligned} & \text { - } \text { sok „ötlet embere” van } \\
& \text { - nyitottak a kommunikációs csatornák } \\
& \text { - } \text { különféle eszközökkel (javaslati-rendszer } \\
& \text { ötletroham) segítik az alkotó rögtönzést }\end{aligned}$ \\
\hline Eredetiség & $\begin{array}{l}\text { - az eredeti emberek elvesztett kreativitásuk után is jogot } \\
\text { formálnak kiváltságokra, és igyekeznek a még valóban } \\
\text { eredetieket ellehetetleníteni, nehogy azok kerüljenek } \\
\text { helyükre } \\
\text { - a specialistákon kívül bevontak és a furcsa viselkedésúek } \\
\text { nem különlegesek, hanem tájékozatlan, naiv laikusok, vagy } \\
\text { rokonok, haverok }\end{array}$ & $\begin{array}{l}\text { - különböző emberek felvételére törekszik } \\
\text { - befogadja a rendkívüli embereket is } \\
\text { - a problémák megoldásába nem csak a } \\
\text { specialistákat vonja be } \\
\text { - elfogadja a furcsa viselkedésformákat }\end{array}$ \\
\hline Információkezelés & $\begin{array}{l}\text { - a kreatív emberek kreatív korszaka rövid } \\
\text { - kreativitásuk elvesztésével } \\
\text { (vagy e helyett, egyszerúen elónyszerzésből) } \\
\text { a hierarchiát tekintik zsinórmértéknek, és ezért olyan } \\
\text { kollégákat juttatnak vezető beosztásba, akik nem } \\
\text { teljesítménycentrikusak }\end{array}$ & $\begin{array}{l}\text { - eljárásai objektívak, tényszerúek } \\
\text { - az ötleteket érdemeik szerint értékeli } \\
\text { (nem aszerint, hogy kitól származnak) } \\
\text { - a kiválasztást és elóléptetést az érdemekre } \\
\text { alapozza }\end{array}$ \\
\hline
\end{tabular}




\begin{tabular}{|c|c|c|}
\hline A kreativitás tényezói & Problémák & A kreatív szervezet tulajdonságai \\
\hline Döntés & $\begin{array}{l}\text { - a hosszú távú tervezés ideáját kifacsarva fiskális } \\
\text { szempontnak (azzz természetesen helytelennek) tart minden } \\
\text { hatékonysági, eredményességi mutatót } \\
\text { - ha (a szervezetnek haszontalan, de) számára hasznos, akkor } \\
\text { sem veti el a szookatlant, ha az a sokadik pillanatban is } \\
\text { ésszerútlennek túnik }\end{array}$ & $\begin{array}{l}\text { - befektet az alapkutatásba - flexibilis, } \\
\text { hosszú távú tervezés } \\
\text { - az új, szokatlan ötleteknek is lehetốséget } \\
\text { ad (kísérletezzget, nem veti el a } \\
\text { szokatlant azért, mert az elsố pillanatban } \\
\text { ésszerútlennek tứnik) }\end{array}$ \\
\hline Stílus & $\begin{array}{l}\text { - a túlságosan demokratikus, kapcsolatorientált stílus } \\
\text { figyelmen kívül hagyja a nyilvánvaló hatékonysági és } \\
\text { eredményességi problémákat } \\
\text { - a hibák megtorlatlansága miatt a munkavállalók értelmetlen } \\
\text { és nyilvánvalóan kudarcba fulladó kockázatokat vállalnak }\end{array}$ & $\begin{array}{l}\text { - decentralizált, diverzifikált } \\
\text { - a hibák kijavítására kelló idót, energiát } \\
\text { fordít } \\
\text { - vállalja a rizikót }\end{array}$ \\
\hline Szabadság & $\begin{array}{l}\text { - a túl sok szociális és jólétit eszkköz miatt a dolgozók inkább } \\
\text { ennek igénybevételében kreatívak } \\
\text { - a megközelítések azért szokatlanok, mert a problémákat } \\
\text { a foglalkoztatottak egyéni és kollektív munkavállalói } \\
\text { jogai kiterjesztésén keresztül közelítik meg, és mellôzzik a } \\
\text { józanságot, valamint a mértékletességet } \\
\text { - mivel mindent meg lehet beszélni, ezért a dolgozóḱ a } \\
\text { szervezetet elsósorban affiliációs igényeik kielégítésére } \\
\text { használják, szakmai kérdések ritkán kerülnek szóba }\end{array}$ & $\begin{array}{l}\text { - nem szigorú szabályok szerint múḱödik } \\
\text { - a dolgozók jól érzik } \\
\text { magukat,- lehetóóséget nyújut a válaszźásra, } \\
\text { a problémák szokatlan megközelítésére } \\
\text { - mindent meg lehet beszélni }\end{array}$ \\
\hline Másság & $\begin{array}{l}\text { - az autonómiára hivatkozva kibújik minden elszámoltatás, } \\
\text { felelésségrevonás alól } \\
\text { - nyilvánvalóo onnérdekét eredeti, szokatlan szervezeti célként } \\
\text { akarja elfogadtatni }\end{array}$ & $\begin{array}{l}\text { - autonóm szervezet } \\
\text { - eredeti, másoktól különálló célok }\end{array}$ \\
\hline Ellentétek egysége & $\begin{array}{l}\text { - a biztonságot kihasználva ellustul } \\
\text { - a kreativitásra létrehozott szervezeti egység mögé bújva } \\
\text { valójában munkakörének tennivalóitól szabadul }\end{array}$ & $\begin{array}{l}\text { - a rutin módszerek biztonsága lehetóvé } \\
\text { teszi az innovációt } \\
\text { - a kreativitásra, az ötletek létrehozására } \\
\text { külön egységek is vannak }\end{array}$ \\
\hline
\end{tabular}

A gyenge erốsségú piaci környezetben múködô tudásalkotó vállalat tipikus megjelenési formája a honi állami egyetem, melyet tekintélyelvú önigazgató szocialista vállalatként jellemezhetünk (Szabó, 2003). E formáció egyik meghatározó eleme a tekintélyelvúi ség, mely lényegében a gyengén ható etikai koordináció fölé kerekedố bürokratikus koordináció meg jelenési formája: az egymásra épülő munkakörökkel jellemezhetô elómeneteli rendszerrel, a céhes múködés donorszervezeti tulajdonságaival.

A tekintélyelvre épülő szolgáltató tipikus szervezete a céh, Sigfried Barr (2005) így is hívja az egyetemeket. Azonos címú könyve összefoglalójából idézzük néhány gondolatát:

,(...) Az egyetem lényege a céhrendszer volt és maradt. (...) Sok minden változott, az egyetem tanai és feladatai, de egyvalami változatlan maradt: az, amitól a nevét kapta, felépitésének lényege, a céhrendszer. Mé az 1968-as lázadás is csak teljesebbé tette a céhet. (...) az egyetem problémája a céh. A formalizmusokban valo rendszeres megmerevedés, a mozdíthatatlanság, a szádfalazás az új emberek és az újdonságok ellen, minde szükségszerüen következik a céhrendszerból (...) Igy a egyetem mindig olyankor volt termékeny, amikor a céh- rendszer elnyomást szenvedett. (...) a virágzó céhrender korszakai mindig a szellemi szárazság korszakai is oltak. Az egyetem összes feladata közül a kutatás fér ossze legkevésbé a céhszerú felépitéssel. A kutatás kezdeményezési tevékenység és a versenyból él. A céhek viszont versenyellenesek."

A céhes múködés alapvetéséhez a tudásszervezet emberieróforrás-gazdálkodását kell áttekinteni, hogy egyértelmúvé váljon a múködési modell alapja. Az állami egyetem egyedi, a szenioritás és vazallusi kötốdés kombinációjaként alkalmazott emberierôforrás-gazdálkodást alkalmaz, amelynek legfontosabb jellemzối a speciális foglalkoztatási viszonyok ${ }^{1}$. Ezek a foglalkoztatási viszonyok alapvetónen a céhes logiḱ́ alo logikén

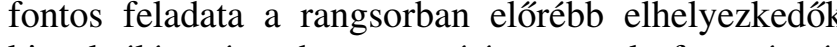
kiszolgalása és tehermentesitése, ennek függvényében haladhatnak a ranglétrán. A haladás egyiranyú, az oldalirányú elágazások nem jellemzőek ${ }^{2}$. Az 1. ábrán az oktatói életkor függvényében mutatjuk be az egyes munkakörökhöz tartozó kötelezô munkaköri elfoglaltságokat (Andor - Rózsás - Szabó - Veres, 2008). Az 1. ábrát öt hazai egyetem ${ }^{3}$ 2001-ben érvényes oktatói-kutatói követelményrendszere alapján készítettük el.
Az ábrán vastaggal jelöltük a szokásos életutat, az tengelyen az életkort jelöltiik.

A munkavállalói elfoglaltság és szenioritás összefüggése heti munkavállalói
elfoglaltság [óra]

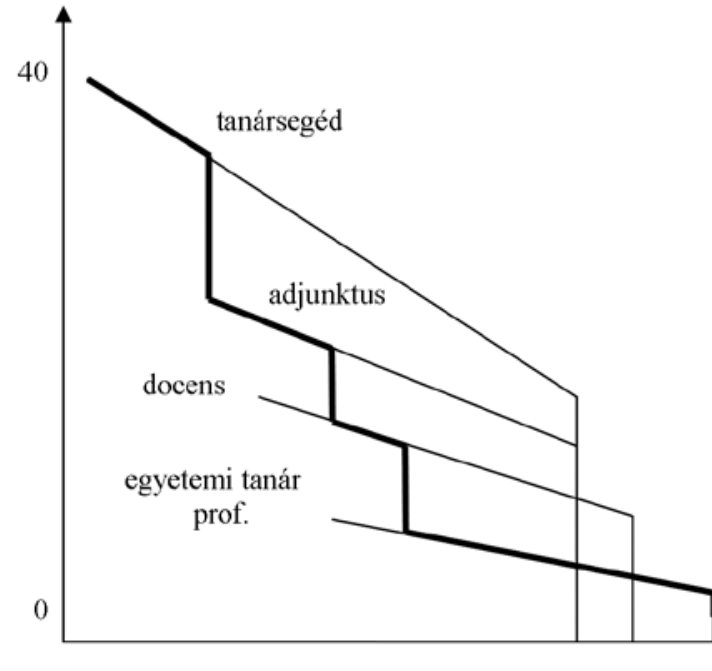
egyes függvények folé beîtuk a hozzájuk tartozó mun-

(a) intsem szolgáltatást igénybe vevő, különleges tudásal rendelkezó és további ilyen megszerzésére szomjazó úbra ügyfeleiknek. Legfốképp azért, mert a hallgatói jogviszonynak álcázott foglalkoztatási jogviszony különösen nagy közteherkedvezményekkel jár, valamint a doktoranduszok foglalkoztatási rugalmassága is páratlan - lényegében szinte semmilyen munkajogi védelmet nem élveznek ${ }^{6}$. A Doktoranduszok Országos Szövetsége szerint ${ }^{7}$ a doktori fokozatnak a versenyszféć doktor fokozalnak a versenyszérában gyakollatilag nincs étcke. Mindezekból azt a következtetést vonjuk le, hogy a doktoranduszok hallgatói státusban szerepeltetése nem más, mint sajátos atipikus foglalkoztatás, és a költségvetés szerv kényszerhelyettesítéses. Fố célja, hogy a (kormányzatnak) ajánlott árnál kevesebbért legyen képes a szervezet feladatát ellátni, így a szervezet (kvázi) tulajdonosai az ebból származó nyereséget feloszthatják. ${ }^{9}$ Járulékos haszna, hogy a doktoranduszokat hallgatóként

A függóleges tengelyen szándékosan „munkaválla- veszik számba, akik ezzel ,javítják” a hatékonysági

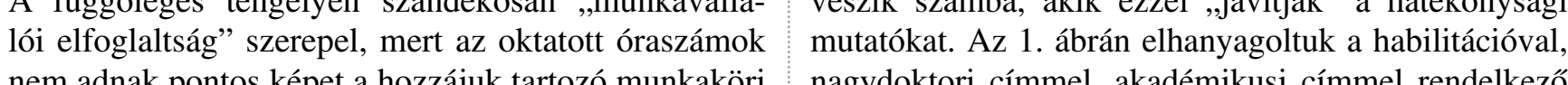
nem adnak pontos képet a hozzajuk tartozó munkaköri nagydoktori címmel, akadémikusi címmel rendelkezố munkamennyiségról. Az alacsonyabb rangú oktatóktól oktatók (jellemző́n egyetemi tanárok) közötti különbugyanis elvárt, hogy olyan oktatásszervezési, rendszer- $\quad$ séget is. A munkaköri rangsorban a munkaköri függfenntartói tevékenységekkel (túzvédelmi, munkavédel- vény meredeksége csökken, ennek oka, hogy az életkor mi felelős, órarendkészítés stb.) foglalkozzanak, ame- növekedésével az idősebb munkavállalók jelentôs kaplyek docensek, tanárok esetében ritka. Az alacsonyabb csolati tókét építenek ki, és - ha rangban nem is érik rangú oktatóktól intenzív kutatási tevékenység is meg- utol a magukkal egykorúakat - általában sikerül kötelekívánt, míg a magasabb rangúak esetében ez már kevés- ző elfoglaltságaikat az azonos korú, rangban magasabbé fontos ${ }^{4}$. Rendszerint nem számít etikai vétségnek, bak közelébe leszorítaniuk ${ }^{10}$.

ha az idôsebb, magasabb rangú kolléga - tóle függő $\quad$ Az életpályafüggvényekból levonható következteelő́menetelú - fiatalabb, alacsonyabb rangúak kutatási tések: eredményét magáénak (is) tekinti (Hargittai, 2006).

A kutatói életpálya szinte az oktatóival azonos, a doktoranduszok ábrázolásától eltekintettünk, mert életciklusuk nagyjából megegyezik a kezdô tanársegédre megállapítottal. Vizsgálatainkból kiderült, hogy a doktoranduszok a BMGE Gazdaság- és Társadalomtudományi Karán meglepő́n alacsony számban szereznek doktori fokozatot (Szabó - Finna - Kövesi, 2005). Az országos adatok sem jobbak, illetve sokk rosszabbak, mint a külhoniak ${ }^{5}$. Úgy túnik, hogy - figyelemmel a nappali tagozatos doktoranduszoknak közvetlenül a képzés végén kiadott doktori fokozatok csekély számára - az egyetemek - megfelelve a tekintélyelvû́, onigazgató szervezet szabályainak - inkább tekintik a) Tekintettel arra, hogy a legalacsonyabb és legmagasabb rangú oktatói munkakörök garantált legkisebb közalkalmazotti illetménye között 2,65-szörö

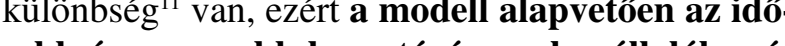
munkavállalók szá-

Az idôsebb és magasabb beosztású munkavállalók - a közalkalmazotti illetményrendszer merevsége miatt - jelentős szabadidőhöz jutnak, amit hasznosságmaximalizálásra használhatnak föl.

c) A hasznosságmaximalizálás irányulhat (1) a szabadidő meghosszabbítására, (2) jövedelemnövelésre ${ }^{12}$, illetve a kettő optimálisnak tekintett kombinációjára. 
d) Az önigazgató szervezetben - a céhes elômeneteli rendszer mellett - a magas beosztású, idôs munkavállalóknak van esélyük a menedzseri pozíció megszerzésére, így a tulajdonosi-menedzseri szerep összevonására ${ }^{1}$

e) A menedzseri hatáskörök többsége tulajdonos szerepet is jelent, így az önigazgató szervezetbe a menedzserek könnyedén képesek a szervezetet az általuk fontosnak tartott célok szolgálatába állítani. A menedzseri és tulajdonosi pozíció az állami szervezetben ugyanakkor szinte kizárólag jogokkal jár, az abban lévớnek kevéssé kell tartaniuk szervezeti kudarctól, felelôsségre vonástól. Koch (1991) - a hazaihoz rendkívül hasonló német felsőoktatásrogyetem nem más, mint államilag támogatott proegyetem nem más, mint államilag támogatott prolalkozás, munkahelyi rizikó nélkül.

f) A tekintélyelvứ ${ }^{14}$, önigazgató állami egyetemen az „egyetemi polgárokon” kívül igazán erốs érdekcsoport nincs, az állami támogatásokat folyósító szervek információhiánya és közömbössége ${ }^{15}$ lényegében nem befolyásolja, hogy a belsô erőforrásokat az egyetem hogyan osztja föl. Ebben a konstrukcióban az egyetemi polgárok tekinthetik magukat kliensnek, ́́gy a legfontosabb kérdés, hogy az eróforás , melyik êrdekcsoport részesul a leginkább, ki az ,igazi Kliens". Nyilvan legtöbb menedzserí és tulajdonosi jogot gyakorolják. g) A függvényból és a kapcsolódó illetményadatokból látszik, hogy idősebb és lehetôleg magas tudományos minősítésú oktatók számára vonzóak az egyetemek $^{16}$. A BMGE adatai ezt nem cáfolják, 2007-es létszám- és életkori adatokat (Sallai, 2007) elemezve látható, hogy:

ha figyelembe vesszük a $\mathrm{kb}$. tanársegédi óraterheléssel rendelkező mintegy 200 fôs nappali tagozatos doktoranduszi létszámot, a munkavállaló életpálya elején és végén kedvelt az egyetemen dolgozni, viszont szembetünő a 35-50 éves korosztály tagjainak hiánya,

a teljes munkaidős oktatói-kutatói létszám átlagéletkos (47,2 ev) is mató-kutón átlageletkora (47,2 év) is magasnak tünik, különösen év), fóleg úgy, hogy az egyenlő́tlen eloszlás miat ev), fổleg úgy, hogy az egyenlôtlen eloszlás miat a legtöbb docens az 56-60 éves, a legtöbb egye
mi tanár a 61-65 éves korcsoportba tartozik, mi tanár a 61-65 éves korcsoportba tartozik, az elózô két francia bekezdést azzal magyarázalacsonyabb bérek oka az alacsony pályakezd bérek és a fiatalság meghosszabbíthatóságának lehetôsége, az idősebbeknél a korporativizmus é a viszonylag alacsony munkaterhelés, valamint az idejében elfoglalt menedzseri pozíciók jelentik a munkahelyi biztonságo

Ennek megfelelóen megállapítható, hogy a BMGE voltaképpen abban nem sokban különbözik a piaci konfigurációktól, hogy a képzett fiatalkorúak foglalkoztatását a középkorúak elé helyezi, hiszen elóbbi nyilvánvalóan olcsóbb. Abban azonban igen, hogy - mivel a szervezetben az idôskorú munkavállalók osztják szét az eróforrásokat és a menedzseri (tulajdonosi) pozíciókat egyaránt - feltúnóen sok az idóskorú múckavállaló. Az államkötrények vállalati hitelekr kavallalo. Az alue gyakorolt un. „, akszrtón hááăhoz hasonlóan az idosskoru munavallaló menedzserek ezért elsósorban a középkorúakat szorítják ki az „egyetemi munkapiac”-ról. Tapasztalataink alapján a „pénzeltérítés" legfóbb címzettjei is az - általában a menedzseri és tulajdonosi jogokat együttesen gyakorló - idôskorú munkavállalók közül kerülnek ki, ami nem meglepő. Az adatok természetesen akár úgy is interpretálhatók, hogy a Múegyetem emberierőforrás-gazdálkodása két alapvetố társadalompolitikai célt egyszerre teljesít. Egyaránt pártolja 1) a fiatal, pályakezdó munkavállalók (a teljes munk idós foglo tejes 1 a a fival palya

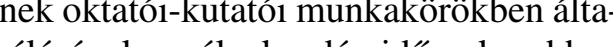
lánossá válásával a palyakezdés idôszaka ebben az ágazatban nintegy ô évvel nốt), valamint a 2) 45 ev felettiek foglalkoztatását. Az utóbbi társadalompolitikai céllal szemben azonban megfogalmazható, hogy a múszaki-természettudományos területen az igazán jelentốs eredmények fiatal felnőttkorban születnek (Kováts, 2007)

$\mathrm{Az}$ egyetemi tanárok szenátusi megszavazásához való ragaszkodás ${ }^{17}$, vagy a $\mathrm{MAB}$ egyetértési joga az egyetemi tanári kinevezésben, az egyetemi tanárok meglehetôsen magas kinevezési (a BMGE-n 50 év) és átlagéletkora legjobban azzal magyarázható, hogy a cím viszonylag sok kiváltsággal, elônnyel jár ${ }^{18}$, így elnyerése meghatározóan (egyetem)politikai döntés. ja ja az intézményen belüli munkapiaci egyensúlyt, és olyan mértekú terhet hárítana az alacsonyabb státusú oktatokra-kutatokra, melyet azok pályaelhagyással büntetnének, ami az intézményi munkapiaci folyamatokat negatív spirálba vinné. Túlságosan alacsony száma viszont veszélyeztetné az egyetemi tanárokhoz kötött szakok, doktori iskolák létét, a szokásosan általuk dominált forrás- és kiváltságosztó helyeken az érintett szervezetek (intézmény, kar, tanszék stb.) pozícióit (Szabó, 2008).

\section{Összefoglaló}

Összefoglalásképpen megállapíthatjuk, hogy bár a hagyományos tudásalkotó vállalatot az különbözteti meg a tudásalkalmazótól, hogy alapvetóen kutatásra, versenyre épül, ennek kialakulásához azonban megfelelô ösztönzók szükségesek. Szélsőséges esetekben, min például gyenge piaci orientációjú, „magára hagyott” állami szervezeteken belül a monopolhelyzetek kialakulás természetes, mint ahogy környezetïkben Különösen az alapvetốn állami t́mogatásrás ben is. Koź́s cüló - egyesülti hagyom anyokal reneavat kozásta epulo - egyesileti hagyomanyokk rendelkezó - egyetemeken nagy a veszélye annak, hogy a piaci koordináció helyeti belsó birokratikus koordináció elsósorban a szervezet befolyásos tagjainak kiszolgálására, érdekeinek védelmére szervezze át a folyamatokat (Tenner - DeToro, 1998). Ennek elkerülésére ma sokan ajánlják a külsố kényszerekkel operáló bürokratikus koordináció növelését, az alacsony erejú ${ }^{19}$ eszközök gyakoribb alkalmazását (Bokros, 2007).

Ezek azonban megfelelố szervezeti kultúrát követelnek, és a „más pénzét másra” költó bürokratikus koordináció (Friedman, 1998) hatékonyságvesztése nem biztos, hogy ellensúlyozni képes az önigazgatás „más pénzét magára” kontrollálatlan önérdekkövetésének csökkenését. A hazai állami egyetemek gazdasági tanács (irányító testület) versus szenátus menedzsment alapproblémája erre (is) vezethető vissza. Feloldásához kézenfekvônek látszik a piaci koordináció eddigieknél erôteljesebb alkalmazása. A közvetlenül érintettek közül leginkább az alkalmazottak, és különösen az oktatók (kutatók) közül az idősebb, magas beosztásúak, fóleg a vezetối megbízással rendelkezók támogatása azonban nem nyerhetố el, mivel pozíciójuk feltehetően romlik, mert menedzseri, tulajdonosi helyzetük gyöngül, megszünik (Andor - Csóke - Szabó - Ormos - Vố - Dér - Pázmándi, 2007). A valód tulajdonost hidegen hagyják az „akadémiai értékek” (a tekintélyelvre alapozott bérezési és elốmeneteli rendszer), annak fizet többe a nyereséghez.

A magánosítás általános tapasztalata, hogy megszúnik a munkaeró másodlagos piacon értékesíthetôsége ami különösen érzékeny veszteség lenne a felsőoktatá munkavállalók nagy részének. Fokozottan vonatkozik ez a vezetốkre, az ô esetükben nom egyszerúen motivációs problémáról, de általában felkészületlenségró is szó van. A tulajdonos igényt tart a nyereségre, nagy részét feltehetôen nem engedi pénzeltérítésként, juttatásként az alkalmazottaknak kifizetni, mert akkor nem maradna elég pénz a fejlesztésekre és saját meggazdagodására.

\section{Lábjegyzet}

Ilyen értelemben valamelyest hasonlít a katonai jellegú pályára, nem véletten, hogy pl. Hasek (1956) Svejkjében jellemzet kedésére meglehetósen hasonlít a félig hallgató, félig oktató-kutató doktoranduszok helyzete.

Jellemző, hogy az egyetem (BMGE) a tudományos kutatókat, vagy a tanszéki mérnököket - a foglalkoztatás tényleges körülményeit tekintve - általában nem (nagyon) különbözteti meg az alacsony státusu oktatói munkakorbe besoroltaktol.

"Osszefoglaló az Operativ Ertekezlet számára az egyetemi oktatók óraterhelési kötelezzettsége tárgyában" múegyetemi kézirat alapjän. A 2005-os felsóoktatasi torveñy az összes oktatóí munfoglaltsá́ ugyanakkor szinte bármi lehet, ami az apít meg. Az elösszefügó́sbe hozható, illetve annak a ténynek fügrvényében, hogy továbbra is rangsorban elóttüik állók döntenek a mögöttüik állók munkaterheléséról, megkockáztatható, hogy a rendelkezés lényeges változásokat nem hozott a terhelések munkaköri megoszlásában.

Darvas Béla interjújában (Nálunk akadémikus az lesz, aki hallgat) utal arra, hogy az akadémikussághoz vezető̉ út is inkább jố affiliációs képességeket, mintsem kiemelkedô tudományos tel je-

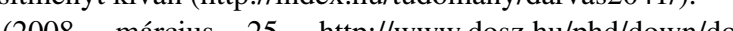
060829_doktori_Europa.pdf)

Amennyiben a doktoránsi státusnak nem az általam említettek lenne célja, akkor a feladat határozott idejú tudományos segédmunkatársi foglalkoztatási jogviszonnyal megoldható lenne. (2008. március 25. http://www.dosz.hu/phd/down/doktori/ 070217_statisztika.pd

„,Ma már szinte minden felsóoktatási intézményben elfogadot gyakorlat, hogy egy-egy tárgyból az elsóo és másodéves
szemináriumait felsóéves târsaik tartják." (Berde, 2005)

"Hasonlóan érvel Szalai Ákos (2004) a nonprofit formák legfontosabb problémája a pénzeltérítés lérásakor. Az adakozók abban a hitben támogatnak valamely szervezetet, hogy az általuk átadott összzeg hiánytalanul az adott szolgaltatást, esetünkben az oktatâst, kutatást finanszírozza. Holott ebból a szempontból a különbség a profiterrdekelt és a nonprofit szervezetek között pusztán annyi, hogy a nyereses más formaban folyik at a könyvelésen. példaul a vezetónek juttatott magasabb fizetésként, a szervezet tulajdonaban marado, de a tulajdonos, a vezetóó személyes hasznalatát szolgälo nagy errtéku lokejavak ként stb. " Forrás: Szalai A. múködés, intézményfinanszírozás. In: Finnnzzínzás és gazdálkodás a felsőkktatásban (Ed. Temesi J.), Aula Kiadó, Budapest, 344-441. o.

A hierarchikus, tekintélyelvú szervezetekben ez gyakori. 2007-es adat (2006. évi CXXVII. törvény a Magyar Köztársaság 2007. évi költségvetéséróll).

Altalános az egyetêttés abban, hogy az intellektuális tóke három alapvetổ összetevő́je: a humán tóke, a strukturális tóke és a kapcsolati tóke együttesen fejezi ki a szervezet tágabb értelemben
vett tudáśst (Tóth. 2003). Az intellektuális tóke menedzelésének lényege, hogy a humán tốkét strukturális tókévé, a strukturális tốkét, pedig kapcsolati tókévé transzformálják. A szituációban a kapcsolati tốke fontosságát erősíti, hogy a professzori-docensi kör - különösen a múszaki-természettudományokat múvelók - olyan életkorban válnak „,vezetó oktatóv́á”, amikor már saját 
intellektuális tókéjüük menedzselési folyamatának utolsó fázisá ban járnak. E munkatársak humán tókéjüuket strukturális tókévé döntő́en ez utóbbit hasznosításával foglalkoznak - szintén összhangban a céhes logikával. Ezzel összefüggéśsben ezért az állan keretekben szervezett tudományos elit életpályája abban szokásosan különbözik más hasonlóan kiugró egyéni képességekre epülókétól, hogy az egyesületi-közszolgálati szervezeti kultúr lényegében ugyanaz a személy. A tekintélyelvre, önigazgatásra és állami apanázsra épüló szervezeti kultúrában ezért a közönsés is majdnem mindig azonos a szereplôkkel, míg pêldául a spordukción nyúitók személye egymástól elválik. E kultúra jellegotes tünetének tartjuk, hogy amennyiben a Múegyetem valamely professzort meg akarta szerezni, abban az esetben ritkán vo professzort meg akarta szerezni, abban az esetben ritkán vo nemzedékek nóhetnének fel tankönyvein, kéziratain, vagy szấmos találmánya, szabadalma van, és tanítványai is hozzá hasonhogy szakindításhoz, doktori iskola indításához kell a "neve", vagy az MTA befolyásos személyisége, mely révén gyorsab . osztó helyekkel, melyekból így bőségesebb pénzforrís vár veló jogviszonyokkal), illetve a hasznosítás költségeit csökkense (például a bevételszerzés intézményi költségeinek másokra hárításával). Az immateriális vagyon mérésének és menedzselésének legnagyobb problémája, hogy önigazgató, tönkre nem mehetó szervezetben a homo oeconomicusok számára a szerveze (bármilyen) vagyon növelése csak akkor lehet cél, ha a szemeválasztások esetén nagyobbak. További probléma hogy a tuhjdonosi-menedzseri szerepeket betöltó̉ munkavállalók kap tókéje hasznosításához szervezet már kevésbé szükséges, ezért munkavállalók általában nem is erôltetik a hasznosítás hasznát a szervezettel megosztani

Polónyi (2006) így írja le az egyetemekhez hasonlóan önigazgató (még onigazgatobb) Magyar Tudományos Akadémia ezzu kapcsolatos helyzetét: „Az Akadémia tagjai és alkalmazot minden jelentösebb hazai kutatási forrás elosztásának kulcspo aciojaban megtalahatok. Kalman C. Gyorgy irodalomtorténesz ugy fogalmazon, hogy „....) befutott, de szakmajjukban már ullügélnek a húsos kondér mellett, vesznek is belóte rendeson cikkek/az-akademi-diszkret-baja), illetve (http ///wwwes hu/p/ display.asp?channel=VISSZHANG0224\&article $=2003-0109$ 1607-22DCCB)

Gabor Kalman: Kollégisták a felsóoktatásban c. tanulmánya ös zzefoglalojaban - a kollegiumba való felvétel kapcsán - szintén nagyot, ha azt gondoljuk, hogy a kollegiumiferohnely-eloszte mint a teljesitményelv, illetve a kollégistákat inkább vezérli a

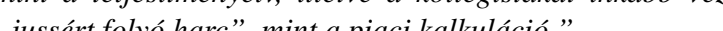
más pénzét költi másra, míg az önigazgató szerverc hatása miatt a (kutatási) szolgâltatást nyújtó és hasznát élvezó loan sikeresek az említettekben. Gyakrabban hivatkoztak arr A homo oeconomicus termézzetes törekvése, hogy a hasznositíssal kapcsolatos bevételeit növelje (például további jövedelemnopénzt osztogatnak, projektekról döntenek." (http:///beszelo c3 h utal a rendies, tekintelyelvú magatartásra: ,...) nem tévedün

„A magasabb minösitésü kutatók jelentós része az idössebb koregyéni kivételekkel - a kutatói aktivitás általában coökken.” Török A. (2006/4.): A krétakör közepén: K+F és innovációs stratégiai dilemmák Magyarországon 2006-ban. Magyar Tudomány, 432. o. Tudomásunk szerint az egyetemi tanárokról minden hazai egyetem a szenátusban dönt, még ha van elózetes kari tanácsi véleménykérés is.

Hasonló gondolatmenettel magyarázza Polónyi (2006) az MTA nagydoktori címek fenntartásat.

lő́dik a vállalat? (Közzazazdasági Szemale, LIV évf: Hogyan fejár, 49-66. o.) c. cikkében meghatározottak szerint használjuk ( A nagy erejü öszzönzók hatékonysági alapon müködnek. Ezzel

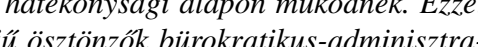
tív jellegüée.")

\section{Felhasznált irodalom}

2005. évi CXXXIX. törvény a felsóoktatásró

6. évi CXXVII. törvény a Magyar Köztársaság 2007. évi Koltségvetésérot

(kadémikus az lesz, aki hallgat (2008) - interjú Darvas Bélával (letöltés ideje: 2008. március 25. http://index.hu/ tudomany/darvas $2041 /$

Andor Gy. - Csóke R. - Szabó T. - Ormos M. - Vó I. - Dér K. - Pazmándi K. (2007): Versenyt akadályozó tényezók a felsoooktatásban, a Gazdasági Versenyhivatal Versenykultúra Központja által a VKK/5/2006. számon kiirt pályázati eljárás keretében támogatott kutatás záró tanulmánya (2007. november)

Andor Gy. - Rózsás P. - Szabó T. - Veres G. (2008): Állami egyetem gazdálkodás- és szervezéstudományi problémái, kutatási zárójelentés: Oktatásért Közalapítvány, Budapest Bär S. (2005): A Céh: Az egyetemek lényege a professzorrâ válásnak és a professzorok érzelmi életének tükrében. Akadémiai Kiadó, Budapest

Berde É. (2005): A diplomázás elő́tt álló fiatalok pályaelképzelései és a munkaügyi statisztikai adatok tényei alapján várható rövid távú tendenciák. OFA, Budapest

Bokros L. (szerk.): Minőségi oktatást és kutatást eredményező reform körvonalai a hazai felsőoktatásban, Vitaanyag (letöltés ideje: 2008. március 25. http://www.es.hu/pd/ display.asp?channel=PUBLICISZTIKA0717\&article= 2007-0430-0855-25ECUU)

Friedman M. (1996): Kapitalizmus és szabadság. BudapestFlorida: Akadémiai-MET

Gábor K. (2006): Kollégisták a felsőoktatásban, Felsőoktatási Kutatóintézet

Gyökér I. - Finna H. - Krajcsák Z. - Szabó T. (2008): Szervezeti viselkedés MSc oktatási segédanyag mesterképzês hallgatói számára, BME MVT

Hargittai I. (2006): Szerepzavarban. Élet és Irodalom, 2006 július 21., 29. szám

Hasek (1956): Svejk Egy derék katona kalandjai a világháborúban. (letöltés ideje: 2008. március 25. http://mek. oszk.hu/01900/01951/html/)

VEZETÉSTUDOMÁNY
Kálmán C. Gy. (2004): A kondér becsülete. Élet és Irodalom, 46. évf. 24. szám

Kapás J. (2007): Hogyan fejlődik a vállalat? Közgazdaság Szemle, LIV. évf., 2007. január, 49-66. o.

Koch C. (1991): Staat und Universität. In: Leviathan 4. sz. Kornai J. (1983): Bürokratikus és piaci koordináció. Közgazdasági Szemle, 9. sz. 1025-1038. o.

Kováts G. (2006): A felsőoktatási intézmények finanszíro zási modelljei. Közgazdasági Szemle, LIII. évf., 2006. któber, 919-938. o.

Di, J. - Finna, H.- Szabó, T. (2005): Teaching Business Disciplines at the Budapest University of Technolog and Economics, Comiltee on Education and Training, . vember, 2005), Budapest, 49-64. o.

Laszioniza L. (200). Dokton képzes - egy kis statisztik (letöltés ideje: 2008. március 25. http://www.dosz.h phd/down/doktori/070217_statisztika.pdf)

Mlecsenkov A. (2001). Összefoglaló az Operatív Értekezl zzámára az egyetemi oktatok oraterhelési kötelezettsé tárgyaban, kezirat, BME

a diszkrét bája, Beszéló, 2006. któber, 11. évfolyam, 10. szám (letöltés ideje: 2008 március 25. hip:/hese diszkret-baja)

Sallai Gy. (2007): BME Humánpolitika és Minőségmenedzsment, kézirat, 2007 (A BME „Professzorok P holy" 2007. november 29-1 ülesén elhangzott előadás ppt. fájljai.)

Szabó T. (2003): Vezetés és szervezés a felsóoktatási intézm nyekben - néhány ok a változásokra, Budapesti Múszaki és Gazdaságtudományi Egyetem, Gazdaság- és Társadalomtudományi Kar, Múhelytanulmányok periodika, Budapest 2003, 61-71. o.

Szabó T (2007): Nonprofit (nonbusiness) menedzsment, Budapesti Múszaki és Gazdaságtudományi Egyetem Gazdaság- és Társadalomtudományi Kar, MBA-képzés, oktatási segédanyag, Budapest

Szabó $T$ (2008): Állami egyetem szervezetének és múködésének elemzése és lehetséges fejlesztési irányai, doktori értekezés, Budapesti Mú́szaki és Gazdaságtudományi Egyetem

Szalai Á (2004): A felsőoktatás intézményi keretei: Intézményi státus és múködés, intézményfinanszírozás in: Finanszírozás és gazdálkodás a felsốoktatásban. (Ed. Temesi J.), Aula Kiadó, Budapest, 344-441. o.

enner, A. R. - DeToro, I. J. (1998): BPR - vállalati folyamatok ujraformálása, Múszaki Konnyvkiadó, Budapest Zs. E. (2003): Az in nek kritikai elemzése, szakdolgozat BME MBA-képzés,

Török Á. (2006): A krétakör közepén: $\mathrm{K}+\mathrm{F}$ és innovációs stratégiai dilemmák Magyarországon 2006-ban. Magyar Tudomány, 2006/4., 432. o.

. A BME humánpolitikája az állami felsôoktatási környezetben, szakdolgozat BME MBA-képzés, Budapest

Zrínyi M. (2005): Tények és lehetóségek a BME tudományos és nemzetközi tevékenységében, a 2005. november 2-i Professzorok Paholya elóadás kézirata (letöltés ideje: prof/200511/profpaholyZM2005.ppt) 